\title{
Model of Chronic Allograft Injury in Alloantibody Positive Renal Transplant Patients
}

\author{
Matthew J. Everly* \\ Terasaki Research Institute, 11570 W. Olympic Blvd, Los Angeles, CA 90064, USA
}

Received: August 19, 2015; Accepted: September 07, 2015; Published: October 31, 2015

*Corresponding author: Matthew J. Everly, Terasaki Research Institute, 11570 W. Olympic Blvd, Los Angeles, CA 90064, USA, Tel: +424-2569106; Fax: +310-445-3381; E-mail: meverly@terasakilab.org

\begin{abstract}
Absract
Despite significant efforts, long-term outcomes in transplantation have not substantially improved over the past few decades. Nonetheless, innovations in immunosuppression have led to the control or a better understanding of T-cell mediated responses. By improving control of the T-cell immune response with immunosuppression, acute cellular rejections have substantially decreased while long-term outcomes remain the same. Transplant researchers have now shifted their focus to the humoral arm of the immune system. It is thought that a significant proportion of transplants experience failure as a result of human leukocyte antigen antibody-mediated injury. Recent studies of the natural history, mechanisms, and pathologic signatures for antibody-mediated injury have led to advancements. This review outlines these advancements and the current understanding of the model of chronic alloantibodymediated injury and describes a path to improve outcomes as they relate to alloantibodies in transplantation.
\end{abstract}

Keywords: Alloantibodies; Human leukocyte Antigen; Organ Transplantation

\section{Introduction}

Improving long-term outcomes has always been a primary focus among researchers and clinicians in solid organ transplant. In the early days of transplant, long-term outcomes were measured in weeks and months. By using immunosuppressive regimens and through innovation in histocompatibility, long-term survival in the late 1960s and 1970s improved many years [1-8]. The half-life of deceased donor kidney transplants performed between 1966 and 1975 was 7.5 years [9]. By the 1980s, primary renal allograft survival was promising, but early acute cellular rejection occurring in $>50 \%$ of the cases seemed to be a barrier for achieving better long-term outcomes [10]. This led to a focus on reduction in early acute cellular rejection rates. However, despite significant advancements in immunosuppression between 1980 and 2000, leading to 1-year acute cellular rejection rates of 10 15\%, long-term survival did not improve [11-13].

Today, the understanding of barriers to improve longterm outcomes has shifted away from preventing acute cellular rejection and has moved toward the humoral theory of transplantation. Since 2003, there has been a steadily increasing focus on anti-HLA antibodies that are directed toward donor
Human Leukocyte Antigens (HLA) (donor-specific anti-HLA antibodies, DSA). Circulating DSA detected after implantation of the donor transplanted organ [de novo immunoglobulin G (IgG) DSA(dnDSA)] are now thought to be the major cause of allograft loss $[14,15]$. In the last 15 years, the body of knowledge on DSA has grown dramatically [14-34]. In the beginning, the research focused on the association between DSA and allograft loss [3336]. With more recent longitudinal studies, there is an increase understanding of the temporal relationship between DSA, DSA changes, and allograft loss [20,37-40]. In addition to the research on DSA, pathology research over the last decade, through clinical and protocol biopsies, has improved the understanding of antibody-mediated injury and chronic rejection pathology $[22,38,41-46]$. This review discusses about the developments in these areas and how together they provide the framework for developing a model of chronic allograft injury in alloantibody positive renal transplant patients.

\section{Incidence and Etiology of DSA}

There are two groups of patients with DSA: those who have HLA antibodies before transplant that are the same serologic specificity as the donor allograft's HLA antigens ("preformed DSA") and those who develop HLA antibodies after transplant directly as a result of an immunologic reaction to the implanted donor HLA antigens on the allograft (dnDSA). In both groups, there is a clear risk of chronic rejection. Approximately 30\% of wait-listed kidney transplant candidates are sensitized to HLA and thus have potential "preformed DSA". The most common means by which a pre-transplant patient may develop non-self HLA antibodies are through blood transfusion and pregnancy. Despite the efforts to find donors against whom these patients have no HLA antibodies, many within this cohort of patients will never be transplanted. Transplanting across HLA antibodies may be the only realistic option for these patients as it is still preferable to stay on dialysis [47].

Post-transplant, it has been shown that $50 \%$ of HLAmismatched primary renal transplant recipients who do not have HLA antibodies to the donor at transplant will later develop IgM HLA DSA [48-50]. Of these patients, half will eventually develop dnDSA (IgG to the same serologic specificity) $[17,18,20,38]$. The majority of dnDSA has been shown to occur in the first post- 
transplant year with a rate of around 10\% [51,52]. The number of new patients who develop dnDSA drops off after the first posttransplant year to about $1-5 \%$ per year, reaching $20 \%$ by 5 -years post-transplantation. Risk factors for dnDSA development include young age (18-35 years of age at transplant), AfricanAmerican ethnicity, DQ mismatch, DR $\beta 1$ mismatch, high total HLA mismatch, deceased donor transplant recipient, and delayed allograft function $[18,20,37,38]$. In addition, dnDSA has been correlated with post-transplant low immunosuppression states such as immunosuppression non-adherence [38,43], posttransplant infection (leading to immunosuppression reduction) $[53,54]$, or physician-directed immunosuppression minimization [55-59].

\section{Allograft Failure with Circulating DSA}

Detection of DSA in a patient's serum is one of the only known predictors for allograft loss. Current studies have investigated the rate of failure following DSA, specifically IgG DSA. In the case of "preformed DSA", the antibody and antigen interact immediately after implantation of the allograft. Conversely, with de novo DSA, there is a response that occurs to the allograft over the first few post-transplant months. The rate at which the humoral response occurs varies among patients depending on the patient's immune system, expression of the alloantigen, and degree of immunosuppression. However, whether the DSA is "preformed" or "de novo", the rate of failure following DSA is similar with respect to the post-transplant time the IgG is first detected in the sera. In the first year following DSA appearance, the risk of allograft failure is 7-9\% [20,60]. By 3-years of postDSA, $21-24 \%$ of patients will progress to chronic alloantibodymediated rejection and failure.

After looking at the post-DSA survival reports, it is clear that many DSA positive patients will have good graft function for three or more years after DSA [60,61]. This stable group accounts for approximately three-fourths of DSA positive patients. This may be primarily due to the each patient's immune system and the degree of immunosuppression. In addition, this could be correlated with the ability and way the allograft heals in the setting of alloantibody-mediated injury. One theory is that with adequate immunosuppression, DSA injury will not outpace endothelial repair. This could make the kidney more resistant to damage over time as donor endothelium could be replaced by recipient endothelium [62-65]. Further studies in this area are needed to fully understand the interaction of the allograft and the immune response.

\section{Models of Chronic Allograft Injury after DSA Appearance}

Recent studies have looked at serial pathology and seral antibody characteristics that correlate with chronic injury and allograft loss $[20,38,46,48,60,66-70]$. The proposed stages from DSA to allograft failure were first described based on the primate study by Smith, et al. [31]. In this study, un-immunosuppressed primates showed rapid deterioration from circulating DSA appearance (stage I), then went on to C4d deposition in the allograft (stage II), which was followed by transplant glomerulopathy (stage III) and ended with a rapid deterioration of allograft function (stage IV). This model however, may differ from the post-transplant human model primarily in the use of immunosuppression. Data from Wiebe, et al. [38] looking at post-transplant (not post-DSA) protocol biopsies in patients with dnDSA has further stratified the model to include peritubular capillaritis within stage II, glomerulonephritis following stage II and prior to stage III, and proteinuria in stage IV.

It is clearly plausible that the stages suggested by Smith, et al; Wiebe, et al. constitute the primary model of chronic alloimmune injury. However, research on complete antibody characterization, chronic rejection pathology, serum and urinary biomarkers, and microRNA indicate that further stratification of this general model is highly likely [71-77]. Recent evidence suggests further characterization of DSA into subclasses can stratify DSA risk groups. IgG3 subclass, in particular, may be an indicator of the poorest allograft prognosis [48]. Aside from DSA, the pathologic finding of inflammation in the area of interstitial fibrosis and tubular atrophy may indicate a different type of DSA positive patient or may just be another stage of alloimmune injury $[42,68,78]$. Regarding serum and urinary biomarkers, ACY1, B2M, CXCL9, and CCL-2 have all been shown to correlate with future graft loss. Finally, detection of Tribbles-1 protein in the blood has been shown to be up regulated during inflammatory events such as chronic antibody-mediated rejection [77]. Future studies combining these tests, with respect to time post-DSA, would yield new information and further lead to the differentiation of the model of chronicity in alloantibody positive transplant patients.

In addition to the accounting for new testing and pathology, the condition that leads to DSA may also play into the fate and course of the model. Patients with non-adherence to medication will likely progress to allograft failure rapidly and may have a vastly different signature than those who have immunosuppression reduction due to BK-virus. In addition, patients who are on near adequate levels of immunosuppression and have stable DSA may progress differently. These differences need to be accounted for the future of model refinement.

\section{Conclusion}

Over the last decade, our understanding of DSA has greatly improved. Moving forward, the next step in improving outcomes in alloantibody positive transplant patients is to obtain a better view of the pathway of chronicity. This can be done through multifaceted, collaborative, longitudinal research that collects and tests all potential markers (pathologic or serologic) together. This research will allow us to identify and differentiate allograft dysfunction risk among the DSA positive patients. Additionally, treatment trials of DSA, based on the current model of chronic allograft injury, have already begun. From these trials, unique information on how a change in pathologic or serologic markers may emerge, thereby adding to our understanding of the model. In all, there is optimism that in the next decade, DSA will be better managed and long-term outcomes will be substantially better in transplantation. 


\section{References}

1. Patel R, Mickey MR, Terasaki PI. Serotyping for homotransplantation. XVI. Analysis of kidney transplants from unrelated donors. N Engl J Med. 1968; 279(10):501-506. doi: 10.1056/NEJM196809052791001.

2. Morris PJ, Williams GM, Hume DM, Mickey MR, Terasaki PI. Serotyping for homotransplantation. XII. Occurrence of cytotoxic antibodies following kidney transplantation in man. Transplantation. 1968;6(3):392-399.

3. Terasaki PI, Kreisler M, Mickey RM. Presensitization and kidney transplant failures. Postgrad Med J. 1971;47(544):89-100.

4. Patel R, Terasaki PI. Significance of the positive crossmatch test in kidney transplantation. N Engl J Med. 1969; 280(14):735-739.

5. Calne RY, Alexandre GP, Murray JE. A study of the effects of drugs in prolonging survival of homologous renal transplants in dogs. Ann N Y Acad Sci. 1962;99:743-761.

6. Schwartz R, Dameshek W. The effects of 6-mercaptopurine on homograft reactions. J Clin Invest. 1960;39:952-958. doi: 10.1172/JCI104116.

7. Schwartz R, Eisner A, Dameshek W. The effect of 6-mercaptopurine on primary and secondary immune responses. J Clin Invest. 1959;38(8):1394-1403. doi: 10.1172/JCI103915.

8. Schwartz R, Stack J, Dameshek W. Effect of 6-mercaptopurine on antibody production. Proc Soc Exp Biol Med. 1958;99(1):164-7.

9. Opelz G, Mickey MR, Terasaki PI. Calculations on long-term graft and patient survival in human kidney transplantation. Transplant Proc. 1977;9(1):27-30.

10. Ferguson R. Acute rejection episodes--best predictor of long-term primary cadaveric renal transplant survival. Clin Transplant. 1994;8(3 Pt 2):328-331.

11.Tantravahi J, Womer KL, Kaplan B. Why hasn't eliminating acute rejection improved graft survival? Ann Rev Med. 2007;58:369-385. doi: 10.1146/annurev.med.58.061705.145143.

12.Lamb KE, Lodhi S, Meier-Kriesche HU. Long-term renal allograft survival in the United States: a critical reappraisal. Am J Transplant. 2011;11(3):450-462. doi: 10.1111/j.1600-6143.2010.03283.x.

13. Terasaki PI. Humoral theory of transplantation. Am J Transplant. 2003;3(6):665-673.

14. Terasaki PI, Cai J. Human leukocyte antigen antibodies and chronic rejection: from association to causation. Transplantation. 2008;86(3):377-383. doi: 10.1097/TP.0b013e31817c4cb8.

15. Einecke G, Sis B, Reeve J, Mengel M, Campbell PM, Hidalgo LG, et al. Antibody-mediated microcirculation injury is the major cause of late kidney transplant failure. Am J Transplant. 2009;9(11):2520-2531. doi: 10.1111/j.1600-6143.2009.02799.x.

16. Bartel G, Regele H, Wahrmann M, Huttary N, Exner M, Horl WH, et al. Posttransplant HLA alloreactivity in stable kidney transplant recipientsincidences and impact on long-term allograft outcomes. Am J Transplant. 2008;8(12):2652-2660. doi: 10.1111/j.1600-6143.2008.02428.x.

17. Cooper JE, Gralla J, Cagle L, Goldberg R, Chan L, Wiseman AC. Inferior kidney allograft outcomes in patients with de novo donor-specific antibodies are due to acute rejection episodes. Transplantation. 2011;91(10):1103-1109. doi: 10.1097/TP.0b013e3182139da1.

18. DeVos JM, Gaber AO, Knight RJ, Land GA, Suki WN, Gaber LW, et al. Donor-specific HLA-DQ antibodies may contribute to poor graft outcome after renal transplantation. Kidney Int. 2012;82(5):598-604. doi: 10.1038/ki.2012.190.
19. Everly MJ, Everly JJ, Arend LJ, Brailey P, Susskind B, Govil A, et al. Reducing de novo donor-specific antibody levels during acute rejection diminishes renal allograft loss. Am J Transplant. 2009;9(5):1063-1071. doi: 10.1111/j.1600-6143.2009.02577.x.

20. Everly MJ, Rebellato LM, Haisch CE, Ozawa M, Parker K, Briley KP, et al. Incidence and impact of de novo donor-specific alloantibody in primary renal allografts. Transplantation. 2013;95(3):410-417. doi: 10.1097/TP.0b013e31827d62e3.

21. Freitas MC, Rebellato LM, Ozawa M, Nguyen A, Sasaki N, Everly $M$, et al. The role of immunoglobulin-G subclasses and $C 1 \mathrm{q}$ in de novo HLA-DQ donor-specific antibody kidney transplantation outcomes. Transplantation. 2013;95(9):1113-1119. doi: 10.1097/ TP.0b013e3182888db6.

22. Gloor JM, Sethi S, Stegall MD, Park WD, Moore SB, DeGoey S, et al. Transplant glomerulopathy: subclinical incidence and association with alloantibody. Am J Transplant. 2007;7(9):2124-2132. doi: 10.1111/j.1600-6143.2007.01895.x.

23. Hourmant M, Cesbron-Gautier A, Terasaki PI, Mizutani K, Moreau A, Meurette A, et al. Frequency and clinical implications of development of donor-specific and non-donor-specific HLA antibodies after kidney transplantation. J Am Soc Nephrol. 2005;16(9):2804-2812. doi: 10.1681/ASN.2004121130.

24. Kaneku H, O'Leary JG, Taniguchi M, Susskind BM, Terasaki PI, Klintmalm GB. Donor-specific human leukocyte antigen antibodies of the immunoglobulin G3 subclass are associated with chronic rejection and graft loss after liver transplantation. Liver Transpl. 2012;18(8):984-992. doi: 10.1002/lt.23451.

25. Lachmann N, Terasaki PI, Budde K, Liefeldt L, Kahl A, Reinke P, et al. Anti-human leukocyte antigen and donor-specific antibodies detected by luminex posttransplant serve as biomarkers for chronic rejection of renal allografts. Transplantation. 2009;87(10):15051513. doi: 10.1097/TP.0b013e3181a44206.

26. Lee PC, Terasaki PI, Takemoto SK, Lee PH, Hung CJ, Chen YL, et al. All chronic rejection failures of kidney transplants were preceded by the development of HLA antibodies. Transplantation. 2002;74(8):11921194. doi: 10.1097/01.TP.0000031249.33030.FB.

27. Lefaucheur C, Loupy A, Vernerey D, Duong-Van-Huyen JP, Suberbielle C, Anglicheau D, et al. Antibody-mediated vascular rejection of kidney allografts: a population-based study. Lancet. 2013;381(9863):313319. doi: 10.1016/S0140-6736(12)61265-3.

28. Martin S, Dyer PA, Mallick NP, Gokal R, Harris R, Johnson RW. Posttransplant antidonor lymphocytotoxic antibody production in relation to graft outcome. Transplantation. 1987;44(1):50-53.

29. Mizutani K, Terasaki P, Rosen A, Esquenazi V, Miller J, Shih RN, et al. Serial ten-year follow-up of HLA and MICA antibody production prior to kidney graft failure. Am J Transplant. 2005;5(9):2265-2272. doi: 10.1111/j.1600-6143.2005.01016.x.

30. Smith JD, Banner NR, Hamour IM, Ozawa M, Goh A, Robinson D, etal. De novo donor HLA-specific antibodies after heart transplantation are an independent predictor of poor patient survival. Am J Transplant. 2011;11(2):312-319. doi: 10.1111/j.1600-6143.2010.03383.x.

31.Smith RN, Kawai T, Boskovic S, Nadazdin O, Sachs DH, Cosimi $\mathrm{AB}$, et al. Four stages and lack of stable accommodation in chronic alloantibody-mediated renal allograft rejection in Cynomolgus monkeys. Am J Transplant. 2008;8(8):1662-1672. doi: 10.1111/j.1600-6143.2008.02303.x.

32. Terasaki PI, Ozawa M. Predictive value of HLA antibodies and serum 
creatinine in chronic rejection: results of a 2-year prospective trial. Transplantation. 2005;80(9):1194-1197.

33. Terasaki PI, Ozawa M, Castro R. Four-year follow-up of a prospective trial of HLA and MICA antibodies on kidney graft survival. Am J Transplant. 2007;7(2):408-415. doi: 10.1111/j.1600-6143.2006.01644.x.

34. Worthington JE, Martin S, Al-Husseini DM, Dyer PA, Johnson RW. Posttransplantation production of donor HLA-specific antibodies as a predictor of renal transplant outcome. Transplantation. 2003;75(7):1034-1040. doi: 10.1097/01.TP.0000055833.65192.3B.

35. Martin J, Worthington J, Harris S, Martin S. The influence of class II transactivator and interleukin-6 polymorphisms on the production of antibodies to donor human leucocyte antigen mismatches in renal allograft recipients. International Journal of Immunogenetics. 2009;36(4):235-239. doi: 10.1111/j.1744-313X.2009.00854.x.

36. Mizutani K, Terasaki P, Bignon JD, Hourmant M, Cesbron-Gautier A, Shih RN,et al. Association of kidney transplant failure and antibodies against MICA. Hum Immunol. 2006;67(9):683-691. doi: 10.1016/j. humimm.2006.06.002.

37. Devos JM, Gaber AO, Teeter LD, Graviss EA, Patel SJ, Land GA, et al. Intermediate-term graft loss after renal transplantation is associated with both donor-specific antibody and acute rejection. Transplantation. 2014;97(5):534-540. doi: 10.1097/01.TP.0000438196.30790.66.

38. Wiebe C, Gibson IW, Blydt-Hansen TD, Karpinski M, Ho J, Storsley LJ, et al. Evolution and clinical pathologic correlations of de novo donor-specific HLA antibody post kidney transplant. Am J Transplant. 2012;12(5):1157-1167. doi: 10.1111/j.1600-6143.2012.04013.x.

39. Burns JM, Cornell LD, Perry DK, Pollinger HS, Gloor JM, Kremers WK, et al. Alloantibody levels and acute humoral rejection early after positive crossmatch kidney transplantation. Am J Transplant. 2008;8(12):26842694. doi: 10.1111/j.1600-6143.2008.02441.x.

40. Kimball PM, Baker MA, Wagner MB, King A. Surveillance of alloantibodies after transplantation identifies the risk of chronic rejection. Kidney Int. 2011;79(10):1131-1137. doi: 10.1038/ki.2010.556.

41. Hidalgo LG, Campbell PM, Sis B, Einecke G, Mengel M, Chang J, et al. De novo donor-specific antibody at the time of kidney transplant biopsy associates with microvascular pathology and late graft failure. Am J Transplant. 2009; 9(11):2532-2541. doi: 10.1111/j.16006143.2009.02800.x.

42. Mannon RB, Matas AJ, Grande J, Leduc R, Connett J, Kasiske B, et al. Inflammation in areas of tubular atrophy in kidney allograft biopsies: a potent predictor of allograft failure. Am J Transplant. 2010;10(9):20662073. doi: 10.1111/j.1600-6143.2010.03240.x.

43. Sellares J, de Freitas DG, Mengel M, Reeve J, Einecke G, Sis B, et al. Understanding the causes of kidney transplant failure: the dominant role of antibody-mediated rejection and nonadherence. Am J Transplant. 2012;12(2):388-399. doi: 10.1111/j.1600-6143.2011.03840.x.

44. Sis B, Campbell PM, Mueller T, Hunter C, Cockfield SM, Cruz J, et al. Transplant glomerulopathy, late antibody-mediated rejection and the ABCD tetrad in kidney allograft biopsies for cause. Am J Transplant. 2007;7(7):1743-1752. doi: 10.1111/j.1600-6143.2007.01836.x.

45. Stegall MD, Park WD, Larson TS, Gloor JM, Cornell LD, Sethi S, et al. The histology of solitary renal allografts at 1 and 5 years after transplantation. Am J Transplant. 2011;11(4):698-707. doi: 10.1111/j.1600-6143.2010.03312.x.

46. Issa N, Cosio FG, Gloor JM, Sethi S, Dean PG, Moore SB, et al. Transplant glomerulopathy: risk and prognosis related to anti-human leukocyte antigen class II antibody levels. Transplantation. 2008;86(5):681-685.

\section{doi: 10.1097/TP.0b013e3181837626.}

47. Montgomery RA, Lonze BE, King KE, Kraus ES, Kucirka LM, Locke JE, et al. Desensitization in HLA-incompatible kidney recipients and survival. N Engl J Med. 2011;365(4):318-326. doi: 10.1056/ NEJMoa1012376.

48. Everly MJ, Rebellato LM, Haisch CE, Briley KP, Bolin P, Kendrick WT, et al. Impact of IgM and IgG3 anti-HLA alloantibodies in primary renal allograft recipients. Transplantation. 2014;97(5):494-501. doi: 10.1097/01.TP.0000441362.11232.48.

49. Farges O, Buffello D, Shi YM, Berth A, Bismuth H: Anti-donor antibody class switching after liver transplantation. Transplantation. 1995;60(3):296-300. doi.

50. Lietz K, John R, Burke E, Schuster M, Rogers TB, Suciu-Foca N, et al. Immunoglobulin M-to-immunoglobulin G anti-human leukocyte antigen class II antibody switching in cardiac transplant recipients is associated with an increased risk of cellular rejection and coronary artery disease. Circulation. 2005;112(16):2468-2476. doi: 10.1161/ CIRCULATIONAHA.104.485003.

51. Heilman RL, Nijim A, Desmarteau YM, Khamash H, Pando MJ, Smith ML, et al. De novo donor-specific human leukocyte antigen antibodies early after kidney transplantation. Transplantation. 2014;98(12):1310-1315. doi: 10.1097/TP.0000000000000216.

52. Huang Y, Ramon D, Luan FL, Sung R, Samaniego M. Incidences of preformed and de novo donor-specific HLA antibodies and their clinicohistological correlates in the early course of kidney transplantation. Clin Transpl. 2012;247-256.

53. Sawinski D, Forde KA, Trofe-Clark J, Patel P, Olivera B, Goral S, et al. Persistent BK viremia does not increase intermediate-term graft loss but is associated with de novo donor-specific antibodies. J Am Soc Nephrol. 2015;26(4):966-975. doi: 10.1681/ASN.2014010119.

54. Libri I, Gnappi E, Zanelli P, Reina M, Giuliodori S, Vaglio A, et al. Trends in immune cell function assay and donor-specific HLA antibodies in kidney transplantation: A 3-year prospective study. Am J Transplant. 2013;13(12):3215-3222. doi: 10.1111/ajt.12503.

55. Shapiro R, Zeevi A, Basu A, Tan HP, Kayler LK, Blisard DM, et al. Alemtuzumab preconditioning with tacrolimus monotherapythe impact of serial monitoring for donor-specific antibody. Transplantation. 2008;85(8):1125-1132. doi: 10.1097/ TP.0b013e31816a8a6d.

56. Hoshino J, Kaneku H, Everly MJ, Greenland S, Terasaki PI. Using donorspecific antibodies to monitor the need for immunosuppression. Transplantation. 2012;93(11):1173-1178. doi: 10.1097/ TP.0b013e31824f3d7c.

57. Kawai T, Sachs DH, Sprangers B, Spitzer TR, Saidman SL, Zorn E, et al. Long-term results in recipients of combined HLA-mismatched kidney and bone marrow transplantation without maintenance immunosuppression. Am J Transplant. 2014;14(7):1599-1611. doi: 10.1111/ajt.12731.

58. Kurata Y, Kuzuya T, Miwa Y, Iwasaki K, Haneda M, Amioka K, et al. Clinical relevance of post-transplant pharmacodynamic analysis of cyclosporine in renal transplantation. Int Immunopharmacol. 2014;22(2):384-391. doi: 10.1016/j.intimp.2014.07.022.

59. Hricik DE, Formica RN, Nickerson P, Rush D, Fairchild RL, Poggio ED, et al. Adverse Outcomes of Tacrolimus Withdrawal in ImmuneQuiescent Kidney Transplant Recipients. J Am Soc Nephrol. 2015; doi: 10.1681/ASN.2014121234.

60. Bentall A, Cornell LD, Gloor JM, Park WD, Gandhi MJ, Winters JL, et al. 
Five-year outcomes in living donor kidney transplants with a positive crossmatch. Am J Transplant. 2013;13(1):76-85. doi: 10.1111/j.16006143.2012.04291.x.

61. Everly MJ, Rebellato LM, Ozawa M, Briley KP, Catrou PG, Haisch CE, Terasaki PI. Influence of Time and Class Specificity of HLA Antibodies on Progression to Acute Rejection and Allograft Loss. Am J Transplant. 2009;9:511-511.

62. Xu W, Baelde HJ, Lagaaij EL, De Heer E, Paul LC, Bruijn JA: Endothelial cell chimerism after renal transplantation in a rat model. Transplantation. 2002;74(9):1316-1320. doi: 10.1097/01.TP.0000034516.92644.38.

63. Bai HW, Shi BY, Qian YY, Na YQ, Zeng X, Zhong DR, et al. Endothelial cell chimerism by fluorescence in situ hybridization in gender mismatched renal allograft biopsies. Chin Med J. 2007;120(10):859-862. doi.

64. Bai HW, Shi BY, Qian YY, Na YQ, Cai M, Zeng X, Zhong DR, Wu SF, Chang JY, Zhou WQ. Does endothelial chimerism correlate with renal allograft rejection? Transplant Proc. 2006;38(10):3430-3433. doi: 10.1016/j. transproceed.2006.10.154.

65. Hruban RH, Long PP, Perlman EJ, Hutchins GM, Baumgartner WA, Baughman KL, Griffin CA. Fluorescence in situ hybridization for the Y-chromosome can be used to detect cells of recipient origin in allografted hearts following cardiac transplantation. Am J Pathol. 1993;142(4):975-980.

66. Cosio FG, Gloor JM, Sethi S, Stegall MD: Transplant glomerulopathy. Am J Transplant. 2008;8(3):492-496. doi: 10.1111/j.16006143.2007.02104.x.

67. Cosio FG, Lager DJ, Lorenz EC, Amer H, Gloor JM, Stegall MD. Significance and implications of capillaritis during acute rejection of kidney allografts. Transplantation. 2010;89(9):1088-1094. doi: 10.1097/ TP.0b013e3181d368f1.

68. Park W, Griffin M, Grande JP, Cosio F, Stegall MD. Molecular evidence of injury and inflammation in normal and fibrotic renal allografts one year posttransplant. Transplantation. 2007;83(11):1466-1476. doi: 10.1097/01.tp.0000265501.33362.d3.

69. Park WD, Griffin MD, Cornell LD, Cosio FG, Stegall MD. Fibrosis with inflammation at one year predicts transplant functional decline. J Am Soc Nephrol. 2010;21(11):1987-1997. doi: 10.1681/ASN.2010010049.

70. Loupy A, Vernerey D, Tinel C, Aubert O, Duong van Huyen JP, Rabant M, et al. Subclinical Rejection Phenotypes at 1 Year Post-Transplant and
Outcome of Kidney Allografts. J Am Soc Nephrol. 2015;26(7):17211731. doi: 10.1681/ASN.2014040399.

71. Welberry Smith MP, Zougman A, Cairns DA, Wilson M, Wind T, Wood SL, Thompson D, Messenger MP, Mooney A, Selby PJ, et al. Serum aminoacylase-1 is a novel biomarker with potential prognostic utility for long-term outcome in patients with delayed graft function following renal transplantation. Kidney Int. 2013;84(6):1214-1225. doi: 10.1038/ki.2013.200.

72. Astor BC, Muth B, Kaufman DB, Pirsch JD, Michael Hofmann R, Djamali A. Serum beta2-microglobulin at discharge predicts mortality and graft loss following kidney transplantation. Kidney Int. 2013;84(4):810-817. doi: 10.1038/ki.2013.172.

73. Juraschek SP, Coresh J, Inker LA, Levey AS, Kottgen A, Foster MC, et al. Comparison of serum concentrations of beta-trace protein, beta2-microglobulin, cystatin $\mathrm{C}$, and creatinine in the US population. Clinical journal of the American Society of Nephrology . Clin J Am Soc Nephrol. 2013;8(4):584-592. doi: 10.2215/CJN.08700812.

74. Suhre K, Schwartz JE, Sharma VK, Chen Q, Lee JR, Muthukumar T, et al. Urine Metabolite Profiles Predictive of Human Kidney Allograft Status. J Am Soc Nephrol. 2015; doi: 10.1681/ASN.2015010107.

75. Suthanthiran M, Schwartz JE, Ding R, Abecassis M, Dadhania D, Samstein B, et al. Urinary-cell mRNA profile and acute cellular rejection in kidney allografts. The New England journal of medicine. 2013;369(1):20-31. doi: 10.1056/NEJMoa1215555.

76. Hricik DE, Nickerson P, Formica RN, Poggio ED, Rush D, Newell $\mathrm{KA}$, et al. Multicenter validation of urinary CXCL9 as a riskstratifying biomarker for kidney transplant injury. Am J Transplant. 2013;13(10):2634-2644. doi: 10.1111/ajt.12426.

77. Ashton-Chess J, Giral M, Mengel M, Renaudin K, Foucher Y, Gwinner W, Braud C, Dugast E, Quillard T, Thebault P, et al. Tribbles-1 as a novel biomarker of chronic antibody-mediated rejection. J Am Soc Nephrol. 2008;19(6):1116-1127. doi: 10.1681/ASN.2007101056.

78. Gourishankar S, Leduc R, Connett J, Cecka JM, Cosio F, Fieberg A, Gaston R, Halloran P, Hunsicker L, Kasiske B, et al. Pathological and clinical characterization of the 'troubled transplant': data from the DeKAF study. Am J Transplant. 2010; 10(2):324-330. doi: 10.1111/j.1600-6143.2009.02954.x. 